February 2022

\title{
Short-term rental versus small hotel industry amid COVID-19 pandemic: What drives millennials' accommodation choices?
}

\section{Tammy Wee}

Singapore Institute of Technology, tammieweeee@gmail.com

Melissa L. S. Liow

PSB Academy, melissa.liow@psb-academy.edu.sg

Follow this and additional works at: https://digitalcommons.usf.edu/jght

Part of the Hospitality Administration and Management Commons, and the Marketing Commons This Refereed Article is brought to you for free and open access by the M3 Center at the University of South Florida Sarasota-Manatee at Digital Commons @ University of South Florida. It has been accepted for inclusion in Journal of Global Hospitality and Tourism by an authorized editor of Digital Commons @ University of South Florida. For more information, please contact digitalcommons@usf.edu.

\section{Recommended Citation}

Wee, T., \& Liow, M. L. (2022). Short-term rental versus small hotel industry amid COVID-19 pandemic: What drives millennials' accommodation choices?. Journal of Global Hospitality and Tourism, 1(1), 69-84. https://www.doi.org/10.5038/2771-5957.1.1.1004

Corresponding Author

Tammy Wee, 10, Dover Road Singapore 138683

Revisions

Submitted: May 19, 2021; 1st Revision: Jul. 20, 2021; 2nd Revision: Sep. 20, 2021; Accepted: Oct. 04, 2021 


\title{
Short-Term Rental Versus Small Hotel Industry Amid COVID-19 Pandemic: What Drives Millennials' Accommodation Choices?
}

\author{
Tammy Wee ${ }^{1}$ and Liow Li Sa Melissa ${ }^{2}$ \\ Singapore Institute of Technology, Singapore \\ ${ }^{1}$ tammieweeee@gmail.com \\ PSB Academy, Singapore \\ ${ }^{2}$ melissa.liow@psb-academy.edu.sg
}

\begin{abstract}
This paper aims to establish the motivation factors behind the accommodation choices made by millennials for stays at short-term rental properties and small hotels amidst the COVID-19 pandemic, a topic that remains under-represented in the hospitality and tourism literature. Using data from a survey of 145 millennials who stayed at an Airbnb property and a small hotel in the past year, a non-parametric test was utilized to compare six motivation factors that affect millennials' accommodation choices, guided by the push-pull motivational framework. The Wilcoxon signed-rank test results showed that the millennials significantly considered price and reviews as their common pull motivations when making accommodation choices. Interestingly, motivation factors such as location, service quality, facilities and amenities, safety, and security do not appear to significantly influence the millennials' choices for either accommodation. This paper contributes to the limited pool of empirical research on short-term rental properties and addresses the challenges faced by the small hotel industry by focusing on millennials' accommodation choices.
\end{abstract}

Keywords: COVID-19, Airbnb, short-term rentals, small hotel industry, millennials, motivation

\section{Introduction}

Web 2.0 has spurred a technological evolution, including social media platforms, peer-to-peer platforms, and Internet-enabled mobile technologies, impacting every industry globally, especially the travel industry (Reinhold et al., 2020). This evolution has kick-started the sharing economy. Among the proliferation of peer-to-peer accommodation sharing platforms, the most representative one is Airbnb which has vastly altered the landscape of the traditional accommodation industry. Airbnb, the epitome of the sharing economy, provides and manages accommodation to millions of travellers without owning any of the properties and solely relying on a networked peer-to-peer sharing platform that is the structure and the foundation of collaborative consumption (Ertz et al., 2016). This market disruption by Airbnb of the tourism accommodation industry has created unprecedented market competition where it has triggered traditional accommodation providers to edify their goods and services to boost their customer appeal (Mishra \& Mohanty, 2020). To stay relevant, some hotels have even resorted to reducing their price to attract more visitors when the competition intensifies, despite the customer 
perception of Airbnb being the more affordable accommodation option (Lu \& Tabari, 2019). In addition, hotels are ramping up their website booking features because travellers who enjoy the social experience are more motivated to book a room via the hotel website platform if featured (Amin et al., 2021). Henceforth smaller hotels, rather than competing ones, are deciding to partner with Airbnb by advertising themselves on the highly surfed Airbnb platform.

Incumbents among the traditional accommodation providers worry about the effect of Airbnb on various establishments, in particular small hotels. Despite its heterogeneity, the feature-by-feature comparison of the product and service offerings between the small hotels and Airbnb short-term rental properties has shown considerable comparability. Some scholarly works found budget- and mid-sized accommodation providers have been negatively impacted by the existence of Airbnb compared to high-end accommodation providers (Basuroy et al., 2020; Zervas et al., 2017), which justifies the evaluation of the small hotel industry rather than high-end hotels. This perspective necessitates scholars to study the collaborative consumption of short-term rentals, including its effect on an established and yet under-explored small hotel industry. Additionally, the COVID-19 pandemic has resulted in an economic super-shock that has hampered all travel globally, adversely affecting the travel and tourism industry throughout the world, including Singapore. The pandemic has challenged the survival of the hospitality industry and presented it with an unprecedented future. With the market disruption from Airbnb and the pandemic, one can imagine their combined stress on the small hotel industry, making this study a worthy pursuit.

According to Statista (2020), 36 per cent of Airbnb users in the US and Europe are between 25 to 34 years old, an attestation that Airbnb is popular among younger consumers, namely the millennial generation (Statista, 2020). With millennials having overtaken the Baby Boomers as the largest generation, they undoubtedly have become the key consumer demographic and will be driving the future trends in the travel and tourism industry (Deane, 2020). With all these considerations, the present study has two primary aims. First, this paper investigates the motivation factors behind the accommodation choices between Airbnb and the small hotel industry amid the COVID-19 pandemic. The rationale is that the small hotel industry shares similarities in practical and experiential dimensions regardless of its heterogeneity. Second, this paper investigates the accommodation choices made by the youngest working generation cohort, the millennials, based on selected motivation factors. A more comprehensive understanding of the motivation factors focusing on the millennials, the future consumers of the tourism industry, can reveal significant marketing insights for small hotel providers and the overall tourism accommodation suppliers during the COVID-19 phenomenon.

\section{Literature Review}

\section{Market Disruption of Short-Term Rentals and Impact on Tourism Accommodation Industry}

For decades, the traditional tourism accommodation providers have been deemed the more reliable suppliers of accommodation. Being more established market players than Airbnb, the traditional tourism accommodation providers anchored to their brand and reputation as a competitive strategy (Dogru et al., 2020). On the contrary, Airbnb and its peer-to-peer platform offer low prices, convenience, and local experiences through community-based tourism, where the residents can earn income from renting their unused space while engaging with their guests (Li et al., 2020). Using technology, Airbnb effectively leveraged the under-utilized capacity that has existed as 
latent market gaps providing a convenient and yet innovative way for anyone to share their accommodation and for anybody to reserve and rent it for a fraction of the standard hotel price (Guttentag \& Smith, 2017). In a few short years, due to its intra-city expansion strategy, Airbnb has expanded to nearly 190 countries, spanning 81 thousand cities (Strommen-Bakhtiar \& Vinogradov, 2020). Airbnb has evolved and challenged to match the accommodation industry in all aspects - variety, rate of expansion, and geographical coverage. Agapitou et al. (2020, p. 4) noted that "Airbnb is growing rapidly, improving its services to attract a broader target group, and drawing from a market where hotels also serve" which highlights the disruption caused by the company on an established industry, specifically, the accommodation industry.

Guttentag \& Smith (2017) found that approximately 67 percent of Airbnb guests who consume its services have seen Airbnb as an acceptable substitute for hotel services. The impact of Airbnb on the accommodation industry is mixed; the most affected are the budget and economy hotels that do not appeal to business travellers and are found to be underperforming when compared to upscale hotels (Zervas et al., 2017). Savolainen (2018) found that the hotels serving low- to mid-markets suffered the most when Airbnb penetrated the tourism accommodation market. These hotels' competitive responses for counteracting Airbnb's presence have been mostly hidden, with many moderating their pricing during peak periods to survive the competitive situation (Savolainen, 2018). Chang \& Sokol (2020) posit that Airbnb's entry has increased the industry heterogeneity resulting in the need for market repositioning for many hotels. Lower-end tier hotels, which often compete on price differentiation, are affected the most. In contrast, upscale hotels are mostly unscathed as they shift to the higher end of the tourist accommodation marketplace (Chang \& Sokol, 2020). Even though many scholars have broadly examined traditional tourism accommodation provider choice, studies using small hotels as a comparison unit to Airbnb are still limited.

\section{COVID-19: An Economic Super-Shock, and Broader Impacts on Singapore's Hospitality Industry}

Despite Airbnb being a successful business story and one of the challenges facing the traditional accommodation providers, there is no escape from the current COVID-19 pandemic disrupting all industries. The COVID-19 pandemic is an economic super-shock that creates adjustments to fundamental macroeconomic variables which could significantly affect economic measures such as consumption, inflation, and job unemployment (The Investopedia Team, 2021). The COVID19 pandemic is projected to induce significant economic shocks to the short-term rental businesses and small hotel industry in three possible ways. First, both would experience the difficulty of finding viable means to survive. For instance, international tourist arrivals have dropped up to 30 percent since the start of the pandemic (UNWTO 2020). Singapore reported tourist arrivals fell 85 percent to 2.7 million visitors, the lowest in four decades because of the COVID-19 pandemic (Tan, 2021). Additionally, the lingering COVID-19 pandemic is projected to drive global growth down to a negative 3 percent (IMF, 2020). Second, the economic shock caused by the pandemic is more intense than any other economic shock, with declines in economic growth twice as large as those produced by regular economic shocks. Third, unprecedented structural changes in various industry sectors are expected because of the global effects of the COVID-19 pandemic super economic shock (Dolnicar \& Zare, 2020). 
Executed as one of the market recovery strategies for the local tourism industry, the Singapore government gave every adult Singaporean citizen, SingapoRediscovers vouchers worth SGD 100 (USD 75) to spend on hotels, attractions, and tours (Lim, 2021). Since the launch of the SingapoRediscovers campaign, local hotel bookings have increased up to threefold as Singaporeans have a limited time to redeem their vouchers via government-approved booking platforms. In addition, the booking platforms under the SingapoRediscovers campaign opened revenue opportunities for the local accommodation providers. The accommodation offered in the campaign includes five-star luxury hotels, but the majority are classified under the small hotel industry; for example, smaller local hotel chains or independent hotel rooms with at least a 2-star rating and offered as low as SGD 60 - SGD 100 (USD 45 - USD 75) per night. As a result, the local travel campaign has provided some financial relief to the local accommodation providers, especially small hotel operators.

However, Airbnb has been facing regulatory issues in its operations, including Singapore, from the pre-COVID-19 days. Airbnb's business model is deemed unlawful in many cities or has been branded as a business that operates an unlicensed platform. In many countries, restrictions have been imposed on Airbnb's hosts' and visitors' activities (Busch, 2019; Zyed et al., 2020) by limiting the days Airbnb hosts can rent out their premises on an annual basis or imposing an occupancy tax on Airbnb's visitors. For instance, in Nashville and New Jersey, hosts can rent out their premises to visitors for a length of stay of not more than 30 days (Mohamad, 2020). In London, hosts are forbidden from renting their properties for more than 90 days, while in Paris, the limit is 120 days (Mohamad, 2020). In Japan and Singapore, the governments allow short-term rentals of private homes to visitors for less than 180 letting-out days, but it is still deemed illegal by the Singapore government. As a result, Airbnb cannot participate in the SingapoRediscovers campaign. To remain competitive in the Singapore accommodation industry during the pandemic, Airbnb has taken an innovative step to position itself as a provider in unique spaces. These unique spaces include heritage shophouses, luxury yachts, pop-out container houses, and distinctive hotel suite rooms. At the same time, Airbnb also features whole Housing Development Board (HDB) apartments for low as SGD 26 (USD 20) per night (Airbnb, 2021). Seeing how the COVID-19 pandemic affects all, the dearth of research comparing the short-term rental market and the small hotel industry is prevalent, even more so during the first wave of the COVID-19 pandemic.

\section{The Future Traveller, Millennials}

A study conducted by Gracia (2019) found millennials to be a key market segment of the homesharing industry. As a key market segment and supporter of the sharing economy, this generational cohort is purportedly motivated by a different set of drivers. Airbnb reported that millennials are motivated by adventure, local, and personal themes (Airbnb Inc., 2016). In a parallel observation, Ketter (2020) found that millennials' travel behavior drives the four key tourism micro-trends: creative tourism, off-the-beaten-track tourism, alternative accommodation, and fully digital tourism. Aceron et al. (2018) conducted a study on millennials who traveled to the Philippines and found their travel behavior to be psychocentric. Starčević \& Konjikušić (2018) further explored behavior among generational cohorts. They found millennials to be digital natives who cause significant shifts in the organizational marketing approaches of the tourism industry. The millennials, therefore, do not actively respond to traditional marketing (Starčević \& Konjikušić, 2018). The intensity of a competitor such as Airbnb, along with the severe economic fallout of the 
COVID-19 pandemic, makes understanding the most influential generation cohort's motivation more critical than ever for the small hotel providers.

\section{Motivation-Based Drivers of Accommodation Choices}

Motivations have been described in several ways but are fundamentally understood as why an individual demonstrates a specific behavior (Herawati et al., 2019). Tourism academicians have acknowledged the innate drives that encourage a person to travel are the push factors. In contrast, the specific characteristics of a travel product that convinces the person to choose one option over others are known as pull factors. Dann's (1981) push-pull motivation framework recognizes that while conceptually distinct, travellers consider both the push factors and pull factors together. This study aims to examine both push and pull motivation factors that millennials would consider behind the accommodation choices they make when choosing between short-term rentals and the small hotel industry amid the COVID-19 pandemic. Dann (1981) explains push motivations as they relate to tourist motivation per se and pull motivation as they relate to travellers choosing products that provide certain benefits. Therefore, this study is positioned as motivation-based because motivation is widely used within tourism studies and is more aligned with the aim of this research where the four push factors (location and accessibility, service quality, facilities, and amenities, safety, and security) and two pull factors (price, guest reviews) are the primary considerations.

Much scholarly work has investigated hotel selection choices, often with the respondents assessing the importance of varying hotel attributes (Goral, 2020; Shah \& Trupp, 2020; Spoerr, 2020). Chan \& Wong (2005) divided these factors into two classifications: (1) tangible, which includes price, appearance, location, presence of alternatives, familiarity, advertising, and incentives, and (2) intangible, which includes security, service quality, and reputation. Jones \& Chen (2010) examined similar attributes affecting hotel selection, such as price, facilities, amenities, online information, and star ratings. The determinant factors affecting the millennials' hotel selection were similar to the aforementioned factors: price, location, amenities, service, impression, and brand image (Silva, 2017).

From these studies, one can summarise that one of the essential factors affecting accommodation selection is price. Tussyadiah \& Pesonen (2018) study identified that cost is a dominant motivation factor for choosing hotels. Dann et al. (2019) also found that Airbnb appeals to visitors with high education, income, IT-savvy, and frequent travellers, but the cost-savings reason is still the primary motivating factor. Although it is posited that the economic benefit is a significant motivating factor in extant literature (Guttentag \& Smith, 2017; Liang et al., 2018), another significant motivation factor lies in the functional attribute, which is the location that consumers perceive as the enhanced value of Airbnb (Guttentag, 2016b). A property's location has been an influential motivation factor, as explored in these studies (Agapitou et al., 2020; Guttentag et al., 2018; Tussyadiah \& Zach, 2015), and was proven to be pivotal in visitors' choice (Agapitou et al., 2020). Tussyadiah $\&$ Zach (2017) found that the visitors enjoyed the unique location offered by the peer-to-peer accommodation rentals. Lin (2020) and Yang \& Mao (2020) highlighted location as the second prime motivator influencing the choice of staying in hotels versus Airbnb-listed premises. These studies proved that location is a significant consideration when it comes to motivation studies. 
Recent studies have explored facilities and amenities (Guttentag, 2016a; Quinby \& Gasdia, 2014; Wang \& Jeong, 2018; Yu et al., 2020) and were proven to be a top-ranked motivation factor to consider. Moreover, Airbnb properties offer access to household amenities as an add-on economical alternative for visitors (Stienmetz et al., 2020). Besides the room-specific factors (facilities and amenities), service quality is also seen as an essential factor in small hotel selection (Li et al., 2020), alongside the chances to experience the home away from home experience and to meet local people in the bed and breakfast hotels (Lin, Lai, \& Morrison, 2019). Service quality had been a significant consideration in the research on the accommodation industry (Dedeoglu \& Demirer, 2015; Wilkins et al., 2007), and as a tourism accommodation provider, Airbnb is not excluded.

The importance of safety and security as a factor in accommodation selection should not be overlooked. Safety regulations have been imposed on established accommodation providers by the law to ensure that the environment is safe and secure for their guests (Feickert et al., 2006). Numerous research (Choi \& Chu, 2001; Chu \& Choi, 2000; Dolnicar \& Otter, 2003) has determined safety and security is a motivation factor in accommodation selection. This is also a common factor that is extensively explored in studies of Airbnb (Shih, 2018). For hotels, intangible factors such as star ratings play an important factor in their selection. Parallel to that, the online reviews, responsiveness of Airbnb hosts, and their engagement on the online booking platform become an essential factor (Tran \& Filimonau, 2020) in Airbnb property selection. Airbnb's networked home-sharing platform enables its users to engage with the hosts where both parties can form a social connection before the Airbnb users' stay (Han et al., 2019). Airbnb users can freely share their experiences (Han et al., 2019) which translates into social benefits gained through the hosts' interaction with its Airbnb users (Jang et al., 2019; Tran \& Filimonau, 2020) making this a vital motivation factor. Cobanoglu et al. (2021) elucidated that tourist destinations need to innovate to assure a competitive and sustainable offer that benefits residents and tourists by creating a cultural tourism experience and facilitating their daily life with information and communication technologies as the intentions of this study.

There is an array of possible push and pull motivations that offer valuable insights into why visitors are motivated to choose hotels and Airbnb, but this body of knowledge is still under-explored in the enduring COVID-19 phenomenon. Another research gap in most of these studies is the investigation focuses on one market: peer-to-peer, short-term rentals in general. It is unlikely to be compared with smaller accommodation providers such as small hotels. Based on Airbnb's adverse effects on the small hotel industry, it makes sense that this paper focuses on the lower-end tier of the accommodation industry rather than the overall hotel industry as a comparative industry due to its overlapping markets. Limited studies, especially during the pandemic, are investigating the participation of millennials in Asian cities, even though Deane (2020) reported that millennials are today's largest generation and a key consumer demographic. As mentioned by Gracia (2019), this generation cohort will unmistakably dictate future travel trends. Thus, the authors of this study decided to focus on the millennials' motivation factors in choosing an accommodation between Airbnb properties and the small hotels amid the COVID-19 pandemic. The motivation factors under study include four push factors (location and accessibility, service quality, facilities, and amenities, safety, and security) and two pull factors (price, reviews) as illustrated in Figure 1. 
Figure 1. Motivation Factors That Affect Millennials' Accommodation Choice

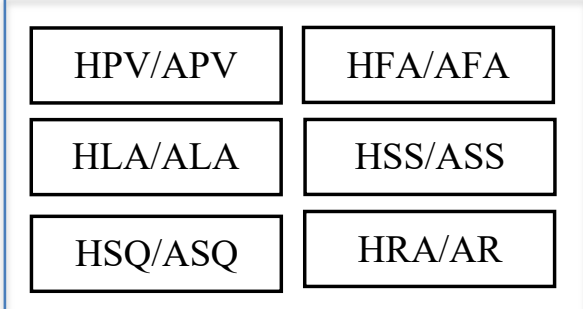

Note. HPV = Hotel Price and Value for Money; APV = Airbnb Price and Value for Money; HLA = Hotel Location and Accessibility; ALA = Airbnb Location and Accessibility; HSQ = Hotel Service Quality; ASQ = Airbnb Service Quality; HFA = Hotel Facilities and Amenities; AFA = Airbnb Facilities and Amenities; HSS = Hotel Safety and Security; ASS = Airbnb Safety and Security; HR = Hotel Reviews; AR = Airbnb Reviews.

\section{Methods}

This study aims to contrast the motivation factors between Airbnb and the small hotel industry amid the COVID-19 pandemic based on the identified motivation factors in Figure I. Figure I shows the various contrasting constructs that are to be included for measurement in the data analysis. The second aim of this study is to examine the millennials' accommodation choices. This study is targeted at millennials 23 to 38 years of age who have experienced booking and staying in small hotels and Airbnb rentals for the past year to contrast the motivation factors between the two types of accommodation. Small hotels were selected as the impact of Airbnb was reportedly higher on them as compared to larger and high-end accommodation providers due to the overlap of markets (Guttentag, 2015; Zervas et al., 2017). In Singapore, small hotels are defined as small enterprises with an annual turnover of more than USD745 thousand (SGD 1 million) but less than USD 7.45 million (SGD 10 million) (Chang \& Rimaud, 2019). For instance, boutique hotels, budget hotels, and motels comprise the vast majority of Singapore's small hotel industry.

The questionnaire is divided into three sections. The first section encompasses the qualifying questions to ensure that the respondent is a millennial and has stayed in small hotels and Airbnb properties. To avoid errors or biases of recall, a timeframe of one year was selected in which the respondents have stayed at least one night in a small hotel and an Airbnb property within the past year. The second section features the motivation factors. The constructs in this section were phrased to contextualize Airbnb rentals and small hotels. The constructs of price, location, service quality, facilities and amenities, safety and security, and reviews are the motivation factors under study. These constructs were sourced from various academic journals (see Table 1). The questionnaire items that operationalize the various constructs were measured on a five-point Likert scale $(1=$ Strongly Disagree and $5=$ Strongly Agree $)$ in an online survey format.

The survey's final section covers the respondents' demographic information such as gender, current employment status, and income level per annum. The participants of the study are millennials living in Singapore. An online survey was selected to encourage the more tech-savvy millennials to participate in the field study phase. The online survey questionnaire was distributed to five volunteer millennials as a form of a pre-testing exercise. The pre-testing exercise was conducted to check for possible phrasing issues such as awkward wording, leading questions, and respondent fatigue and to check the reliability and validity of the survey questions. After the pre- 
testing exercise, some questionnaire wordings were rephrased to address the face, content, and construct validity issues.

Table 1. Operationalization of Motivation Factors

\begin{tabular}{ll}
\hline Motivation Factors & Scholarly Work \\
\hline Price & Guttentag \& Smith (2017); Liang et al. (2018); Tussyadiah \& Pesonen (2018) \\
Location & Agapitou et al. (2020); Guttentag et al. (2018); Tussyadiah \& Zach (2015) \\
Facilities and Amenities & Guttentag (2016a, b); Quinby \& Gasdia (2014); Wang \& Jeong (2018); Yu et al. (2020) \\
Service Quality & Dedeoglu \& Demirer (2015); Wilkins et al. (2007) \\
Safety and Security & Choi \& Chu (2001); Chu \& Choi (2000); Dolnicar \& Otter (2003); Feickert et al. (2006) \\
Reviews & Han et al. (2019); Jang et al. (2019); Tran \& Filimonau (2020) \\
\hline
\end{tabular}

In the field study, respondents are requested to read, and they must consent before participating in the online survey. Purposive sampling, a non-random sampling approach, was utilized to target millennials who fulfilled the qualifying questions. The survey was distributed at the height of the COVID-19 pandemic between April to June 2020 using Qualtrics, an online questionnaire software via a link, and yielded 145 valid responses.

After completing the data collection phase, the data was cleaned and checked for missing values, outliers, and any errors that might affect any statistical result. Finally, a reliability test was conducted, and Cronbach's alpha score of .915 indicated the questionnaire had achieved acceptable reliability. The Wilcoxon signed-rank test was proposed as the statistical analysis for this study because the constructs were measured at the ordinal level. However, after running the normality test, which found the data does not follow a normal distribution, the authors decided to proceed with the analysis using the non-parametric statistical test, Wilcoxon signed-rank test.

\section{Data Analysis}

The authors have conducted a non-parametric statistical hypothesis test, the Wilcoxon signed-rank test, based on the selected constructs of price, location, service quality, facilities and amenities, safety and security, and reviews. From the 145 valid responses, the respondents' demographic information - gender, current employment status, and current income per annum - is summarised in Table 2.

\section{Results}

As shown in Table 2, the representation of each gender is almost equal, with male respondents at $56 \%$ and female respondents at $44 \%$. Since male and female respondents are almost equally represented, the concern about gender bias is minimal. Most of the respondents are fully employed $(59 \%)$ or are students $(32 \%)$. Millennials who are unemployed (4\%), self-employed (4\%), or under part-time employment (1\%) make up the remaining $9 \%$ of the 145 respondents. As for their income level in US Dollars (USD) or Singapore Dollars (SGD), most respondents earned between USD 14,900 - USD 33,500 or SGD 20,000 - SGD 44,999 (44\%), approximately 39\% of the respondents earned less than USD 149,000 or SGD $20,000,12 \%$ earned USD 33,500 - USD 74,500 or SGD 45,000 - SGD 99,999, and 5\% of the respondents earned USD 745,000 or SGD 100,000 and above. 
Table 2. Socio-Demographic Profile of Respondents $(\mathrm{n}=145)$

\begin{tabular}{lcc}
\hline Characteristic & Frequency & Percentage \\
\hline Gender & 81 & 56 \\
Male & 64 & 44 \\
$\quad$ Female & $\mathbf{1 4 5}$ & $\mathbf{1 0 0}$ \\
$\quad$ Total & & \\
Employment Status & 86 & 59 \\
$\quad$ Full-Time Employment (44 Hours per & 46 & 32 \\
Week) & 6 & 4 \\
Student & 5 & 4 \\
Unemployed & 2 & 1 \\
Self Employed & $\mathbf{1 4 5}$ & $\mathbf{1 0 0}$ \\
Part-Time Employment (Less Than 35 & & \\
Hours per Week) & 57 & 39 \\
Total & 64 & 44 \\
Income per Annum & & \\
Less Than USD 14,900 or SGD 20,000 & 12 \\
USD 14,900 - USD 33,500 or SGD 20,000- & 17 & 5 \\
SGD 44,999 & & $\mathbf{1 0 0}$ \\
$\quad$ USD 33,500 - USD 74,500 or SGD 45,000- & 7 & \\
SGD 99,999 & $\mathbf{1 4 5}$ & \\
USD 74,400 and Above or SGD 100,000 & & \\
and Above & & \\
Total & &
\end{tabular}

After running the Wilcoxon signed-rank test on the constructs identified in Figure I, the authors found that the p-value of the following constructs - location, service quality, facilities and amenities, and safety and security - are not significant. In other words, these four constructs do not have an apparent influence on the millennials' choice to stay in small hotels or Airbnb properties. However, the two motivation factors of price ( $p$-value .014) and reviews ( $p$-value .003) do have a significant influence on the millennials' choice to stay in small hotels or Airbnb properties (Table 3).

Table 3. Wilcoxon Signed-Rank Test on the Motivation Factors of Small Hotels and Airbnb

\begin{tabular}{lc}
\hline Motivation Factor & $\boldsymbol{P}$-Value \\
\hline Price & $\mathbf{. 0 1 4}$ \\
Location & .431 \\
Service Quality & .124 \\
Facilities \& Amenities & .332 \\
Safety and Security & .145 \\
Reviews & $\mathbf{. 0 0 3}$ \\
\hline
\end{tabular}

\section{Discussion}

Even during the COVID-19 pandemic, authors found price has a significant influence within the motivation factors under investigation in this study. This finding is aligned with the result outcomes of other studies (Gong \& Zheng, 2018; Guttentag et al., 2018; Tran \& Filimonau, 2020) on the influence of price when making accommodation choices. Li et al. (2013) explained that millennials are the youngest generation among the working cohorts, and many are in the early and mid-stages of their formal careers. Because of this, millennials are more price-conscious, and with their IT savviness, millennials do not hesitate to search for price deals via online travel platforms. In addition, McKinsey reported in the Asia Travel Leader Summit (n.d.) that the Asian millennials prefer short holidays and travel to short-haul destinations, and they do not mind traveling on budget airways or staying in budget accommodations to fulfil their travel desires within their means. 
Guest reviews are another noteworthy motivation factor determining the millennials' booking choice to stay in a small hotel or an Airbnb property. This result is in line with the findings by Tran \& Filimonau (2020), in which this motivation factor becomes essential when selecting accommodation via online platforms. Reviews include peer-to-peer feedback and host-guest interaction. Interactive communication creates digital transparency in Airbnb and facilitates building trust among its users (Dredge \& Gyimóthy 2017). Millennials who grew up in the connected world with the internet and smartphones were appreciative of connection and interaction with strangers. Booking online for an Airbnb property or a small hotel and reading and posting reviews enable millennials to engage in genuine socio-cultural exchanges with the local community. This view has remained unchanged during the COVID-19 pandemic.

However, location, service quality, facilities and amenities, and safety and security were found not to have a significant influence on the millennials' choices to stay in a small hotel or an Airbnb property. These results contrast with claims made in other studies (Guttentag et al., 2018; Quinby \& Gasdia, 2014; Wang \& Jeong, 2018; Yu et al., 2020; Yua \& Wang, 2020). Several studies have considered location one of the main factors (Agapitou et al., 2020; Guttentag et al., 2018; Tussyadiah \& Zach, 2015). However, the results in this study showed that millennials do not emphasize geographical elements. In a similar vein, Guttentag et al. (2018) expressed reservations on location being an important consideration when making accommodation booking choices. Millennials see themselves as more receptive to new ideas, are more adventurous (Jspeert \& Hernandez-Maskivker, 2020), and do not mind staying in a unique location. According to Folmer et al. (2019), they tend to partake in experiential and transformative travel that requires them to travel to non-touristy or off-the-beaten track destinations to experience the authentic local lifestyle, customs, and culture, thus they place less emphasis on the location of the property. Moreover, during the COVID-19 pandemic, many countries, including Singapore, closed borders, practiced stricter travel restrictions, and applied domestic lockdown measures (Ren, 2020). As a result, many people, including the millennials, found themselves limited to domestic travel. Thus, location is no longer viewed as a crucial motivating factor during the pandemic.

Even though it is one of the most cited motivation factors in hospitality-related studies (Raza et al., 2012; Ryan, 1991; Wong Ooi Mei et al., 1999; Wu \& Ko, 2013), service quality was found to be a non-motivation factor for millennials when making accommodation choices. One plausible reason is that many scale measurements developed for the different hospitality motivation studies are incommensurable, negating potential comparisons among the studies. For example, in this study, the service quality was focused on 'personalized service' in hotels (McIntosh \& Siggs, 2005, as cited in Guttentag et al., 2018) versus 'host-guest interaction' in Airbnb properties (Ekinci, 2002). Another probable reason is as the public has become more aware of health risks, their travel decision-making choices have been altered (Huang et al., 2019; Kim et al., 2020; Otoo \& Kim, 2018; Page et al., 2012). As influenced by the health risks of the pandemic, many have changed their perception about service quality, with more requesting contactless service and self-service management rather than human service.

Many studies include facilities and amenities as considerations in the motivation studies (Agapitou et al., 2020; Guttentag, 2016a; Quinby \& Gasdia, 2014; Wang \& Jeong, 2018; Yu et al., 2020). However, in this study, facilities and amenities as a construct is not a motivating factor. Tussyadiah \& Zach (2015) claimed that although guests are fixated with facilities and amenities, they also value their stay experiences and deem them more critical. This might explain why facilities and 
amenities is not the primary criteria for millennials to consider when deciding to book with a small hotel or an Airbnb property in this study. Moreover, because the pandemic has highlighted the need for social distancing, facilities and amenities may not be one of their considerations. The perception of home-sharing, including sharing facilities and amenities, is not appealing to many travelers now due to health risks. Future travellers will likely choose the accommodation that can reassure hygiene and cleanliness as part of the accommodation package, rather than facilities and amenities. The motivation factor, safety, and security has been a concern for many sharing economy-related studies (Agapitou et al., 2020; Malazizi et al., 2018; Rauch \& Schleicher, 2015). However, during the pandemic, most travelers are more concerned about health risks than safety and security, which could be the plausible reason this motivation factor has not been a significant factor in the millennials' accommodation choices.

\section{Conclusions}

Designing trust as part of a business model is not easy, even for Airbnb. However, as a small hotel provider, it is possible to learn a few tricks from the sharing economy business model by having a reciprocal reputation system where hosts and guests can rate each other. Additionally, small hotel providers are already at an advantage in providing guarantees to their existing guests. In contrast, Airbnb recently started to implement its guest guarantee after a history of leaving their customers to deal with bad hosts. Responding timely and positively to bad reviews is recommended for small hotel providers as this will enhance the millennial guests' after-stay experience.

To promote the shared value trend, small hotel providers are encouraged to associate their brand with the pursuits of social and environmental goals. Millennial guests are more aware of their traveling habits and their impact on the environment. The small hotel providers could take a step further by featuring their support in the local community, such as sourcing their food products from local farms and promoting environmental protection efforts such as environmental-related clean-ups. Lastly, the present paper recommends that the small hotel providers delve into guests' perceptions of the cleanliness and hygiene of their accommodations. Apart from creating a transparent communication channel, small hotel providers are also encouraged to invest in contactless services or have the option of self-service for the guests in accordance with the change in travel sentiments during the pandemic. Nonetheless, the small hotel industry is encouraged to continue offering tangibles and intangibles that forge experiences. Developing a well-known, easily recognized, and consistent brand identity is more crucial than ever. Thus, marketing strategies must emphasize maintaining good relationships with existing and prospective customers and fulfilling guest needs and expectations (Ali et al., 2021).

\section{Limitations and Further Research}

Even though it reveals exciting insights and contributes to the current knowledge in the study of Airbnb and small hotels, this study has its limitations. There are pluralism issues in definitions that could pose a measurement error for the motivation factors, resulting in measurement inconsistency among studies. This study recommends that a more standardized definition be developed to ensure that the measurements are more comparable. Careful treatment in the operationalization of the constructs is one suggestion. Exploring the health, cleanliness, and hygiene factor as a mediator or moderator in future research is another suggestion to gain further insights into the extent of the COVID-19 pandemic on accommodation selection choices. 
While the sample size was sufficient for the planned statistical analyses, cautions are to be exercised for the generalizability of the findings. The authors suggested a bigger sample size to mitigate this issue. Although gender bias was accounted for, using a purposive sampling technique means that sample biases associated with sampling frames could affect the results. Nonetheless, the almost equal representativeness of the sample lends confidence to the validity of the research.

Another limitation of this study is that this study's sample was limited to one generational cohort who resides in one geographical area. This could potentially affect the findings, as respondent exhibit their regional characteristics. Thus, it would be beneficial to expand the research to a broader geographical area for regional comparisons for future research. It would also be illuminating to investigate decision motivations across all generational cohorts.

The present research contributed to the existing research on motivation studies by concentrating on the youngest generational working cohort's accommodation choices, the millennials. In addition, this study's findings added to the existing research by identifying the two significant motivation factors, price, and review, which remained valued by millennials, one of the most influential generational cohorts today. With these findings, the present study has discussed some practical marketing approaches for the small hotel industry in this age of the sharing economy and the COVID-19 pandemic.

\section{Implications}

This study aims to determine if any specific motivation factors influence millennials' decision to stay in a small hotel or an Airbnb. It offers insights into two areas: Theoretical and Practical Implications.

\section{Theoretical Implications}

Conceptual models such as Dann's (1981) push-pull motivation framework help in the present study to provide the basic framework for motivations and other scholastic works. The results of this study establish that even during the COVID-19 pandemic, price and reviews remain a significant influence within the motivation factors investigated in this study. However, location, service quality, facilities and amenities, and safety and security were found not to have a significant influence on the millennials' choices to stay in a small hotel or an Airbnb property. Thus, the current study offers a unique insight in terms of theoretical understanding of millennials' motivations that affect their decision-making behaviour during extraordinary times, such as the current COVID-19 pandemic.

\section{Practical Implications}

Several recommendations can be made for practitioners from these findings, especially the small hotel providers operating during the pandemic. Apart from keeping prices economical, the small hotel providers need to recognize the importance of peer-to-peer feedback, host interaction, and digital transparency, the human side of the sharing economy. Small hotel providers could connect with the millennials by identifying with the trends associated with the sharing economy concept, such as community, trust, and the shared value of sustainability and local experiences. As millennials are attracted to these trends, it is vital for small hotel providers to promote these trends. For example, a small hotel provider could work with the local community to offer local 
W ee and Liow: Short-term rental versus small hotel industry amid COVID-19 pandemic: What drives millennials' accommodation choices?

experiences, a massive draw for the millennials as they value authenticity. There is also the desire to connect with their hosts as they form a stay experience for the guest; small hotel owners and employees must be prepared to interact with the millennial guests to generate that much-valued positive electronic word-of-mouth.

\section{References}

Aceron, R. M., Del Mundo, L. C., Restar, A. S. N., \& Villanueva, D. M. (2018). Travel and tour preferences of millennials. Journal of Economics and Management Sciences, 1(2), 141-151. https://doi.org/10.30560/jems.v1n2p141

Agapitou, C., Liana, A., Folinas, D., \& Konstantoglou, A. (2020). Airbnb is customers' choice: Empirical findings from a survey. Sustainability, 12(15), 1-13. https://doi.org/10.3390/su12156136

Airbnb Inc. (2016, November). Airbnb and the rise of millennial travel. https://www.airbnbcitizen.com/wpcontent/uploads/2016/08/MillennialReport.pdf

Ali, F., Dogan, S., Turktarhan, G., \& Cobanoglu, C. (2021). Hospitality brands: What so consumers want? University of South Florida M3 Center. https://www.doi.org/10.5038/M3-HTIR.003

Amin, M., Ryu, K., Cobanoglu, C., \& Nizam, A. (2021). Determinants of online hotel booking intentions: Website quality, social presence, affective commitment, and e-trust. Journal of Hospitality Marketing \& Management, 30(7)1-26. https://doi/abs/10.1080/19368623.2021.1899095

Asia Travel Leaders Summit. (n.d.). Capturing the Asian millenial traveler. Retrieved November 7, 2021, from https://www.visitsingapore.com/content/dam/MICE/Global/bulletin-board/travel-rave-reports/Capturingthe-Asian-Millennial-Traveler.pdf

Basuroy, S., Kim, Y., \& Proserpio, D. (2020, June 11-13). Estimating the impact of Airbnb on the local economy: Evidence from the restaurant industry [Paper presentation]. 42nd ISMS Marketing Science Conference, Durham, NC, USA.

Busch, C. (2019). Regulating Airbnb in Germany-Status quo and future trends. Journal of European Consumer and Market Law, 8(1), 39-41.

Chan, E. S. W., \& Kong, S. C. K. (2005). Hotel selection: When price is not the issue. Journal of Vacation Marketing, 12(2), 142-159. https://doi.org/10.1177\%2F1356766706062154

Chang, H. H., \& Sokol, D. D. (2020). How incumbents respond to competition from innovative disruptors in the sharing economy: The impact of Airbnb on hotel performance. Strategic Management Journal. Advance online publication. https://doi.org/10.1002/smj.3201

Chang, Y., \& Rimaud, C. (2019). 14 Small and medium-sized enterprises' financing in Singapore. In N. Yoshino, \& F. Taghizadeh-Hesary (Eds.), Unlocking SME finance in Asia: Roles of credit rating and credit guarantee schemes (pp. 316-336). Routledge.

Choi, T. Y., \& Chu, R. (2001). Determinants of hotel guests' satisfaction and repeat patronage in the Hong Kong hotel industry. International Journal of Hospitality Management, 20(3), 277-297. https://doi.org/10.1016/S0278-4319(01)00006-8

Chu, R. K., \& Choi, T. (2000). An importance-performance analysis of hotel selection factors in the Hong Kong hotel industry: A comparison of business and leisure travelers. Tourism Management, 21(4), 363-377. https://doi.org/10.1016/S0261-5177(99)00070-9

Cobanoglu, C., Dogan, S., Berezina, K., \& Collins, G. (Eds.) (2021). Advances in hospitality and tourism information technology. University of South Florida M3 Center. https://digitalcommons.usf.edu/m3publishing/vol18/iss9781732127586/

Dann, G. M. (1981). Tourist motivation: An appraisal. Annals of Tourism Research, 8(2), 187-219. https://doi.org/10.1016/0160-7383(81)90082-7

Dann, D., Teubner, T., \& Weinhardt, C. (2019). Poster child and guinea pig-insights from a structured literature review on Airbnb. International Journal of Contemporary Hospitality Management, 31(1), 427-473. https://doi.org/10.1108/IJCHM-03-2018-0186

Deane, S. (2020, May 15). Over 60 Millennial travel statistics. Stratos. https://www.stratosjets.com/blog/millennialtravel-statistics/

Dedeoglu, B. B., \& Demirer, H. (2015). Differences in service quality perceptions of stakeholders in the hotel industry. International Journal of Contemporary Hospitality Management, 27(1), 130-146. https://doi.org/10.1108/IJCHM-08-2013-0350 
Dogru, T., Mody, M., Line, N., Suess, C., Hanks, L., \& Bonn, M. (2020). Investigating the whole picture: Comparing the effects of Airbnb supply and hotel supply on hotel performance across the United States. Tourism Management, 79, 1-13. https://doi.org/10.1016/j.tourman.2020.104094

Dolnicar, S., \& Otter, T. (2003, January 1). Which hotel attributes matter? A review of previous and a framework for future research. Institutional Repository for the University of Wollongong. https://ro.uow.edu.au/cgi/viewcontent.cgi?article=1281\&context=commpapers

Dolnicar, S., \& Zare, S. (2020). COVID19 and Airbnb-disrupting the disruptor. Annals of Tourism Research, 83, 14. https://doi.org/10.1016/j.annals.2020.102961

Dredge, D., \& Gyimóthy, S. (2017). Collaborative economy and tourism: Perspectives, politics, policies and prospects. Springer.

Ekinci, Y. (2002). A review of theoretical debates on the measurement of service quality: Implications for hospitality research. Journal of Hospitality and Tourism Research, 26(3), 199-216. https://doi.org/10.1177\%2F1096348002026003001

Ertz, M., Durif, F., \& Arcand, M. (2016). Collaborative consumption: Conceptual snapshot at a buzzword. Journal of Entrepreneurship Education, 19(2), 1-23. http://dx.doi.org/10.2139/ssrn.2799884

Feickert, J., Verma, R., Plaschka, G., \& Dev, C. S. (2006). Safeguarding your customers: The guest's view of hotel security. Cornell Hotel and Restaurant Administration Quarterly, 47(3), 224 - 244. https://doi.org/10.1177\%2F0010880406288872

Folmer, A., Tengxiage, A. T., Kadijk, H., \& Wright, A. J. (2019). Exploring Chinese millennials' experiential and transformative travel: A case study of mountain bikers in Tibet. Journal of Tourism Futures, 5(2), 142-156. https://doi.org/10.1108/JTF-02-2019-0018

Gong, J., \& Zheng, Y. (2018). A study on the motivation and constrain factors influence Chinese travelers' attitude towards Airbnb [Unpublished Master's Thesis]. Uppsala University.

Goral, R. (2020). Prioritizing the factors which affect the selection of hotels by consumers travelling for vacation with Analytical Hierarchy Process (AHP) method. Journal of Tourism Management Research, 7(1), 11-31. https://doi.org/10.18488/journal.31.2020.71.11.31

Gracia, M. B. (2019). Collaborative consumption in the hospitality sector: Analysis of the customer experience in hotels and Airbnb. Repositorio Comillas. https://repositorio.comillas.edu/xmlui/handle/11531/27473

Guttentag, D. (2015). Airbnb: Disruptive innovation and the rise of an informal tourism accommodation sector. Current Issues in Tourism, 18(12), 1192-1217. https://doi.org/10.1080/13683500.2013.827159

Guttentag, D. (2016a). Airbnb: Why tourists choose it and how they use it [Master's thesis, University of Waterloo]. Waterloo's Intuitional Repository. https://uwspace.uwaterloo.ca/bitstream/handle/10012/10684/Guttentag_Daniel.pdf?sequence=1\&isAllowed=y

Guttentag, D. (2016b). Why tourists choose Airbnb: A motivation-based segmentation study underpinned by innovation concepts. Waterloo's Intuitional Repository. https://uwspace.uwaterloo.ca/bitstream /handle/10012/10684/Guttentag_Daniel.pdf

Guttentag, D. A., \& Smith, S. L. (2017). Assessing Airbnb as a disruptive innovation relative to hotels: Substitution and comparative performance expectations. International Journal of Hospitality Management, 64, 1-10. https://doi.org/10.1016/j.ijhm.2017.02.003

Guttentag, D., Smith, S., Potwarka, L., \& Havitz, M. (2018). Why tourists choose Airbnb: A motivation-based segmentation study. Journal of Travel Research, 57(3), 342-359.

Han, H., Shin, S., Chung, N., \& Koo, C. (2019). Which appeals (ethos, pathos, logos) are the most important for Airbnb users to booking? International Journal of Contemporary Hospitality Management, 31(3), 12051223. https://doi.org/10.1108/IJCHM-12-2017-0784

Herawati, H., Prajanti, S. D. W., \& Kardoyo, K. (2019). Predicted purchasing decisions from lifestyle, product quality and price through booking motivation. Journal of Economic Education, 8(1), 1-11. https://journal.unnes.ac.id/sju/index.php/jeec/article/view/29636

Huang, D., Liu, X., Lai, D., \& Li, Z. (2019). Users and non-users of P2P accommodation. Journal of Hospitality and Tourism Technology, 10(3), 369-382. https://doi.org/10.1108/JHTT-06-2017-0037

IMF. (2020). World economic outlook: The great lockdown. International Monetary Fund. https://www.imf.org/en/Publications/WEO/Issues/2020/04/14/weo-april-2020

The Investopedia Team. (2021, July 31). Economic shock. Investopedia https://www.investopedia.com/terms/e/economic-shock.asp

Jang, J., Choi, J., Jeon, H., \& Kang, J. (2019). Understanding US travelers' motives to choose Airbnb: A comparison of business and leisure travelers. International Journal of Tourism Sciences, 19(3), 92-209. https://doi.org/10.1080/15980634.2019.1664006 
W ee and Liow: Short-term rental versus small hotel industry amid COVID-19 pandemic: What drives millennials' accommodation choices?

Jones, P., \& Chen, M. M. (2010). Factors determining hotel selection: Online behaviour by leisure travelers. Tourism and Hospitality Research, 11(1), 83-95. https://doi.org/10.1057\%2Fthr.2010.20

Ketter, E. (2020). Millennial travel: Tourism micro-trends of European Generation Y. Journal of Tourism Futures, 7(2), 192-196. https://doi.org/10.1108/JTF-10-2019-0106

Kim, J., Kim, J., Lee, S. K., \& Tang, L. R. (2020). Effects of epidemic disease outbreaks on financial performance of restaurants: Event study method approach. Journal of Hospitality and Tourism Management, 43, 32-41. https://doi.org/10.1016/j.jhtm.2020.01.015

Li, X., Li, X. R., \& Hudson, S. (2013). The application of generational theory to tourism consumer behaviour: An American perspective. Tourism Management, 37, 147-164. https://doi.org/10.1016/j.tourman.2013.01.015

Li, H., Liu, Y., Tan, C. W., \& Hu, F. (2020). Comprehending customer satisfaction with hotels. International Journal of Contemporary Hospitality Management, 32(5), 1713-1735.

Liang, L. J., Choi, H. C., \& Joppe, M. (2018). Understanding repurchase intention of Airbnb consumers: Perceived authenticity, electronic word-of-mouth, and price sensitivity. Journal of Travel \& Tourism Marketing, 35(1), 73-89. https://doi.org/10.1080/10548408.2016.1224750

Lim, J. (2021, March 19). Families flock to hotels for March holiday staycations amid Covid-19. The Strait Times. https://www.straitstimes.com/singapore/consumer/flurry-of-bookings-for-staycations-during-march-schoolholidays-hotels-say-covid

Lin, P. M. (2020). Is Airbnb a good choice for family travel? Journal of China Tourism Research, 16(1), 140-157. https://doi.org/10.1080/19388160.2018.1551167

Lin, Y. C., Lai, H. J., \& Morrison, A. M. (2019). Social servicescape and Asian students: An analysis of spring break island bed and breakfast experiences in Taiwan. Tourism Management Perspectives, 31, 165-173. https://doi.org/10.1016/j.tmp.2019.04.005

Lu, L., \& Tabari, S. (2019). Impact of Airbnb on customers' behaviour in the UK hotel industry. Tourism Analysis, 24(1), 13-26. https://doi.org/10.3727/108354219X15458295631891

Malazizi, N., Alipour, H., \& Olya, H. (2018). Risk perceptions of Airbnb hosts: Evidence from a Mediterranean Island. Sustainability, 10(5), 1-23. https://doi.org/10.3390/su10051349

Mcintosh, A. J., \& Siggs, A. (2005). An exploration of the experiential nature of boutique accommodation. Journal of Travel Research, 44(1), 74-81. https://doi.org/10.1177/0047287505276593

Mishra, S. P., \& Mohanty, B. (2020). Approaches to strategy formulations: A content analysis of definitions of strategy. Journal of Management \& Organization. Advance online publication. https://doi.org/10.1017/jmo.2019.86

Mohamad, N. A. (2020). Saying 'yes' or 'no' to short-term holiday letting in stratified properties in Malaysia. International Journal of Business and Society, 21, 137-151.

Otoo, F. E., \& Kim, S. S. (2018). Is there stability underneath health risk resilience in Hong Kong inbound tourism? Asia Pacific Journal of Tourism Research, 23(4), 344-358.

Page, S., Song, H., \& Wu, D.C. (2012). Assessing the impacts of the global economic crisis and swine flu on inbound tourism demand in the United Kingdom. Journal of Travel Research, 51(2), 142-153.

Quinby, D., \& Gasdia, M. (2014, July). Share this! Private accommodation and the rise of the new gen renter. Phocuswright. https://www.phocuswright.com/Travel-Research/Research-Updates/2014/Share-ThisPrivate-Accommodation-the-Rise-of-the-New-Gen-Renter

Rauch, D. E., \& Schleicher, D. (2015). Like Uber, but for local governmental policy: The future of local regulation of the "sharing economy" (George Mason University Law and Economics Research Paper Series, 15-01). Social Science Research Network. http://dx.doi.org/10.2139/ssrn.2549919

Raza, M., Siddiquei, A., Awan, H., \& Bukhari, K. (2012). Relationship between service quality, perceived value, satisfaction and revisit intention in hotel industry. Interdisciplinary Journal of Contemporary Research in Business, 4(8), 788-805.

Ren, X. (2020). Pandemic and lockdown: A territorial approach to COVID-19 in China, Italy and the United States. Eurasian Geography and Economics, 61(4-5), 423-434.

Reinhold, S., Zach, F. J., \& Laesser, C. (2020). E-business models in tourism. In Z. Xiang, M. Fuchs, U. Gretzel, \& W. Höpken (Eds), Handbook of e-tourism (pp. 1-30). Springer.

Ryan, C. (1991). Analyzing service quality in the hospitality industry using the SERVQUAL model. The Service Industries Journal, 11(3), 324-345. https://doi.org/10.1080/02642069100000049

Savolainen, J. (2018). Hotel industry competitive responses against Airbnb: A case study of hotels vs. Airbnb in Helsinki. Aalto University, Learning Centre. http://urn.fi/URN:NBN:fi:aalto-201806293962

Shah, C., \& Trupp, A. (2020). Trends in consumer behaviour and accommodation choice: Perspectives from India, Anatolia, 31(2), 244-259. https://doi.org/10.1080/13032917.2020.1747213 
Shih, C. W. (2018). Hotel vs. Airbnb: What attributes do travelers value the most?. [Master's thesis, California State Polytechnic University Pomona]. ScholarWorks. https://broncoscholar.library.cpp.edu/bitstream/handle/10211.3/206645/WengShihCheng_Project2018.pdf

Silva, A. M. (2017). Hotel management and the generational impact of Millennials and IGEN: What can hotel market learn with generational cohorts? [Doctoral disssertation, Escola Superior de Hotelaria e Turismo do Estoril]. Repositorio Comum. https://comum.rcaap.pt/bitstream/10400.26/19722/1/2017.04.007_.pdf

Spoerr, D. (2020). Factor analysis of hotel selection attributes and their significance for different groups of German leisure travelers. Journal of Quality Assurance in Hospitality and Tourism, 22(3), 312-335.

Starčević, S., \& Konjikušić, S. (2018, May 31- June 2). Why millennials as digital travelers transformed marketing strategy in tourism industry [Paper Presentation]. The Third International Scientific Conference, Vrnjacka, Serbia.

Statista. (2020, August 9). Share of Airbnb users by age group in the United States and Europe 2017. Statista. https://www.statista.com/statistics/796646/airbnb-users-by-age-us-europe/

Strommen-Bakhtiar, A., \& Vinogradov, E. (2020). The Adoption and development of airbnb services in Norway: A regional perspective. In M. Khosrow-Pour (Ed.), Destination management and marketing: Breakthroughs in research and practice (pp. 32-44). IGI Global.

Tan, A. (2021, February 1). Spore's tourist arrivals fell $85 \%$ to $2.7 \mathrm{~m}$, lowest in four decades due to Covid-19. The Strait Times. https://www.straitstimes.com/singapore/consumer/27-million-visitors-in-singapore-in-2020lowest-in-four-decades-due-to-covid-19

Tran, T. H., \& Filimonau, V. (2020). The (de)motivation factors in choosing Airbnb amongst Vietnamese consumers. Journal of Hospitality and Tourism Management, 42, 130-140. https://doi.org/10.1016/j.jhtm.2019.10.011

Tussyadiah, I. P., \& Zach, F. J. (2015, May 15-17). Hotels vs. peer-to-peer accommodation rentals: Text analytics of consumer reviews in Portland, Oregon [Paper presentation]. Travel and Tourism Research Association (TTRA) 46th Annual International Conference, Portland, Oregon, USA.

Tussyadiah, I. P., \& Zach, F. (2017). Identifying salient attributes of peer-to-peer accommodation experience. Journal of Travel and Tourism Marketing, 34(5), 636-652. https://doi.org/10.1080/10548408.2016.1209153

Tussyadiah, I. P., \& Pesonen, J. (2018). Drivers and barriers of peer-to-peer accommodation stay-An exploratory study with American and Finnish travelers. Current Issues in Tourism, 21(6), 703-720. https://doi.org/10.1080/13683500.2016.1141180

UNWTO. (2020, March 26). International tourist arrivals could fall by 20-30\% in 2020. World Tourism Organization, https://www.unwto.org/news/international-tourism-arrivals-could-fall-in-2020

Wang, C. R., \& Jeong, M. (2018). What makes you choose Airbnb again? An examination of users' perceptions toward the website and their stay. International Journal of Hospitality Management, 74, 162-170. https://doi.org/10.1016/j.ijhm.2018.04.006

Wilkins, H., Merrilees, B., \& Herington, C. (2007). Towards an understanding of total service quality in hotels. International Journal of Hospitality Management, 26(4), 840-853. https://doi.org/10.1016/j.ijhm.2006.07.006

Wong Ooi Mei, A., Dean, A. M., \& White, C. J. (1999). Analyzing service quality in the hospitality industry. Managing Service Quality: An International Journal, 9(2), 136-143. https://doi.org/10.1108/09604529910257920

Wu, H. C., \& Ko, Y. J. (2013). Assessment of service quality in the hotel industry. Journal of Quality Assurance in Hospitality and Tourism. 14(3), 218-244. https://doi.org/10.1080/1528008X.2013.802557

Yang, Y., \& Mao, Z. (2020). Location advantages of lodging properties: A comparison between hotels and Airbnb units in an urban environment. Annals of Tourism Research, 81, 1-13. https://doi.org/10.1016/j.annals.2020.102861

Yu, M., Cheng, M., Yu, Z., Tan, J., \& Li, Z. (2020). Investigating Airbnb listings' amenities relative to hotels. Current Issues in Tourism. Advance online publication. https://doi.org/10.1080/13683500.2020.1733497

Yua, J., \& Wang, K. Y. (2020). Online evaluation and tourist booking behaviours for urban homestay selection. International Journal of Innovation, Creativity, and Change, 13(6), 208-219.

Zervas, G., Proserpio, D., \& Byers, J. W. (2017). The rise of the sharing economy: Estimating the impact of Airbnb on the hotel industry. Journal of Marketing Research, 54(5), 687-705. https://doi.org/10.1509\%2Fjmr.15.0204

Zyed, Z. A. S., Yong, M. Y., \& Tedong, P. A. (2020). Public users' perception of Airbnb in Malaysia: Should we regulate? Property Management, 38(5), 627-642. https://doi.org/10.1108/PM-09-2019-0050 